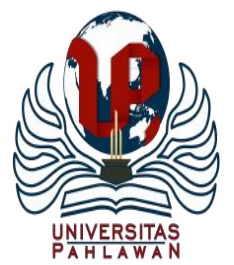

Edukatif : Jurnal Ilmu Pendidikan Volume 3 Nomor 5 Tahun 2021 Halm 2993 - 2999

EDUKATIF: JURNAL ILMU PENDIDIKAN

Research \& Learning in Education

https://edukatif.org/index.php/edukatif/index

\title{
Gaya Kepemimpinan Kepala Sekolah Dasar dalam Membentuk Karakter Warga Sekolah
}

\author{
Riki Batubara $^{1 凶}$ Rusdinal $^{2}$, Nurhizrah Gistituati ${ }^{3}$ \\ Universitas Negeri Padang, Indonesia ${ }^{1,2,3}$ \\ E-mail : $\underline{\text { Rikibatubara5@gmail.com }}^{1}, \underline{\text { Rusdinal@ fip.unp.ac.id }}^{2}, \underline{\text { Icha_yp@yahoo.com }}^{3}$
}

\begin{abstract}
Abstrak
Pengelolaan suatu sekolah dipengaruhi oleh gaya kepemimpinan, gaya kepemimpinan merupakan suatu cara yang dimiliki oleh kepala sekolah dalam melaksanakan kepemimpinan khusus di SDN 12 Lembah Melintang Pasaman Barat. Tujuan penelitian ini adalah mengambarkan gaya kepemimpinan kepala sekolag di SD Negeri 12 Lembah Melintang Pasaman Barat dalam membentuk karakter warga sekolah. Metode penelitian kualitatif. Informan penelitian ini kepala sekolah, guru dan warga sekolah. Teknik analisis data menggunakan data kualitatif. Hasil penelitian mengambarkan bahwa gaya kepemimpinan yang digunakan kepala sekolah yang menghargai setiap ide yang dimiliki guru dan mendiskusikan dari setiap kebijakan yang akan diambil, membangun karakter siswa di sekolah kepala sekolah menerapkan beberapa aspek diantaranya kedisiplinan, tanggungjawab, kerjasama. Hasil wawancara yang dilakukan dengan kepala sekolah, mampu menerapkan nilai-nilai terutama religius setiap hari jumat siswa secara bergiliran setiap kelas melalkukan kultum, kantin jujur dan menerapkan disiplin di sekolah
\end{abstract}

Kata Kunci: gaya kepemimpinan, karakter.

\section{Abstract}

The management of a school is influenced by leadership style, leadership style is a way that the principal has in carrying out special leadership at SDN 12 Lembah Melintang Pasaman Barat. The purpose of this study is to describe the leadership style of the head of school at SD Negeri 12 Lembah Melintang Pasaman Barat in shaping the character of school residents. Qualitative research methods. The informants of this study were principals, teachers and school residents. The data analysis technique used qualitative data. The results of the study illustrate that the leadership style used by the principal who respects every idea that the teacher has and discusses any policies that will be taken, builds the character of students in the principal's school applying several aspects including discipline, responsibility, cooperation. The results of interviews conducted with the principal, were able to apply values, especially religious, every Friday, students took turns each class doing cults, honest canteens and applying discipline at school

Keywords: leadership style, character.

Copyright (c) 2021 Riki Batubara, Rusdinal, Nurhizrah Gistituati

$\triangle$ Corresponding author

Email : Rikibatubara5@gmail.com

DOI : https://doi.org/10.31004/edukatif.v3i5.998

ISSN 2656-8063 (Media Cetak)

ISSN 2656-8071 (Media Online) 
2994 Gaya Kepemimpinan Kepala Sekolah Dasar dalam Membentuk Karakter Warga Sekolah - Riki Batubara, Rusdinal, Nurhizrah Gistituati

DOI: https://doi.org/10.31004/edukatif.v3i5.998

\section{PENDAHULUAN}

Kepala sekolah adalah aspek penting harus ada di sekolah, berjalannya roda organisasi sekolah perlu dibina oleh seorang pimpinan yaitu kepala sekolah, kepemimpinan merupakan bagian dari manajemen, untuk mencapai tujuan sekolah perlu disepakati bersama harus ada yang memipin. Sekolah akan berjalan efektif jika ada seseorang yang memimpin, sekolah yang bermutu ditentukan oleh kepemimpinan kepala sekolah, kepala sekolah mempunyai peranan penting dalam menerapkan nilai-nilai karakter yang ada disekolah. Untuk menciptakan suatu organisasi yang berkualitas yang baik,maka dibutuhkan pemimpin yang baik dan jujur. Peran kepala sekolah sangat penting dalam membangun budaya sekolah yang harmonis baik antara guru dan kepala sekolah, kepala sekolah dengan siswa dan guru dengan siswa dengan adanya terjadalin kearaban dan rasa kekeluargaan akan tercipta suasana sekolah yang menyenangkan dan iklim sekolah yang dapat membuat warga sekolah lebih betah di sekolah dari pada dirumah, kepala sekolah mampu membangun kerjasama sama warga di sekitar lingkungan sekolah yang dijadikan fatner dalam membangun sekolah, keterlibatan. Seorang pimpinan haruslah memiliki kemampuan sesuai dengan kompetensinya masing masing. Namun dalam kenyataan kompetensi yang dilaksanakan di sekolah sering situasional yang ada di sekolah. Kondisi ini sering terjadi di sekolah dasar dengan berbagai alasan diantaranya kurangnya mengikuti pelatihan-pelatihan, seminar worskhop maupun studi kepemimpinan (Marianti, Razak Umar, \& Ruwiah A. Buhungo, 2019).

Fenoma yang terjadi di SDN 12 lembah Melintang kepala sekolah menerapkan sekolah berbasis karakter, jadi kepala sekolah bersama warga sekolah membuat kesepakatan dan kebijakan bersama membangun karakter Bulding dalam membangun karakter di sekolah. Kepala sekolah terbuka dalam mengembangkan karakter siswa,kepala sekolah memberikan kebebasan kepada guru untuk mengembangkan karakter siswa di sekolah, alasan kepala sekolah menerapkan ini karena setiap hari siswa selalu bersama guru, untuk melakukan aktivitas tentu guru yang lebih tahu dan mengerti tentang karakter siswanya. Berdasarkan hal di atas penulis tertarik menuangkan kedalam sebuah tulisan yang berjudul Gaya Kepemimpinan Kepala Sekolah Di SD Negeri 12 Lembah Melintang Pasaman Barat Dalam Membentuk Karakter Warga Sekolah, pembinaan dilakukan secara bertahap dan tidak bisa secara instan, pembinaan karakter ini dilakukan oleh kepala sekolah dengan memberikan keteladanan.

Pembinaan karakter juga termasuk dalam materi yang harus diajarkan dan diukasai serta direalisasikan oleh peserta didik dalam kehidupan sehari-hari (Kamaruddin, Murniati, \& Niswanto, 2016), Pendidikan karakter bukan hal yang baru dalam sistem pendidikan nasional Indonesia. Upaya mendidik anak-anak menjadi pribadi yang baik, perlu diwujudkan bersama sebagai prioritas dalam hubungan kerjasama antara keluarga, masyarakat maupun pemerintah khususnya melalui bidang pendidikan. Sistem pendidikan nasional tersebut, sangat jelas bahwa pendidikan di Indonesia diharapkan tidak hanya menitikberatkan pada kecerdasan intelektual saja namun penting memperhatikan penanaman nilai-nilai karakter pada siswa dan pengembangan kultur (budaya) sekolah sebagai aspek pembentukan karakter (Claudy Yanar Yasuka, 2018). Berdasarkan fenomena di atas sangat perlu dilakukan penelitian ini berkaitan dengan pembinaan karakter yang dilakukan oleh kepala sekolah.

\section{METODE PENELITIAN}

Jenis penelitian ini kualitatif deskriptif. Lokasi penelitian SD Negeri 12 Lembah Melintang Pasaman Barat. Informasi penelitian ini guru, satpam sekolah dan siswa. Teknik pengumpulan data menggunakan lembar observasi dan wawancara. Teknik analisis data terdiri dari pengumpulan data, analisis data dan penarikan kesimpulan (Arikunto, 2010). 
2995 Gaya Kepemimpinan Kepala Sekolah Dasar dalam Membentuk Karakter Warga Sekolah - Riki Batubara, Rusdinal, Nurhizrah Gistituati

DOI: https://doi.org/10.31004/edukatif.v3i5.998

\section{HASIL DAN PEMBAHASAN PENELITIAN}

Gaya Kepemimpinan Kepala Sekolah SD 12 Lembah Melintang. Kepala sekolah memiliki peranan penting dalam membangun karakter siswa di sekolah, dengan membagun nilai-nilai karakter akan tercipta kecerdasan emosional di dalam diri siswa ada rasa tanggungjawab dan rasa peduli dengan lingkungannya, susksesnya pengembangan karakter di sekolah tidak telepas dari dukungan warga sekolah yang dipimpin oleh kepala sekolah secara langsung, akan berbeda nilainya jika kepada sekolah kurang mendukung dalam pengembangan karakter siswa. Gaya kepemimpinan yang digunakan oleh kepala sekolah dalam mengembangkan karakter kepemimpinan demokrastis semua keputusan yang dibuat oleh kepala sekolah tidak secara langsung tetapi mendiskusikan terlebih dahulu dengan semua warga sekolah dilakukan dengan musyawarah dan mufakat harus ditaati oleh semua warga sekolah Berdasar beberapa hal terse but, maka pendidikan karakter menjadi sala satu program alternatif untuk memperbaharui keadaan sebagaimana digambarkan di atas. Pelaksanakan pendidikan karakter pada setting persekolahan dianggap sebagai salah satu instrumen terpenting (Satim, 2013).

Hasil wawancara dengan guru X bawa penanaman nilai-nilai karkater disekolah dilakukan dengan cara kepala sekolah membuat forum diskusi tentang penerapan atau mengembangkan nilai karakter yang ada disekolah, apa saja komponen yang perlu dikembangkan dari kesepakatan yang dilakukan komponen yang dikembangkan adalah karakter jujur, karakter disiplin dan karakter kerjasama serta karakter religius. Pengembangan karakter saat ini bukanlah mudah tetapi diperlukan konsistensi dari semua warga sekolah untuk melakukan dan menerapkannya. Hasil wawancara yang dilakukan dengan siswa di sekolah mereka menjawab bahwa disekolah selalu dilaksanakan sholat berjamaah dan melakukan kultum setiap hari juma;at, jika ada siswa yang melanggar peraturan dengan sendiri siswa mengakuinya dan menerima hukuman sesuai dengan apa yang telah disepakati sebelumnya, bagi siswa laki-laki yang tidak melaksanakan sholat akan diberikan sanksi yang membangun, sehingga besoknya siswa tidak melanggar lagi dari aturan yang dibuat disekolah, sekolah saat ini sedang membangun karakter bulding dimana kepala sekolah dapat menjadi teladan dari semua warga sekolah tanpa terkecuali. Kepala sekolah selalu mendiskusikan dari setiap aspek yang ditemui pelanggaran didalam pelaksanaanya, kepala sekolah mempercayai semua guru untuk mengontrol setiap kegiatan yang dilakukan berkaitan dengan peningkatan karakter siswa, siswa yang berkater akan dilihat dari etika dan perilaku yang diperlihatkan setiap hari di sekolah.

Sejalan dengan penelitian yang dilakukan oleh (Widodo, 2018), (Trihantoyo, 2015) (Gaib, Najamuddin Pettasolong, \& Satria Koni, 2019) Pendidikan merupakan bimbingan dan pertolongan secara sadar yang mampu diberikan kepada manusia sesuai dengan perkembangan jasmani dan rohani ke arah pemahaman yang ia miliki. Manusia dalam mencari nilai-nilai hidup, harus mendapat bimbingan sepenuhnya dari manusia lainnya yang dipandang lebih tahu (Guna \& Tugas, 2016).

Budaya/kultur sekolah adalah tradisi sekolah yang tumbuh dan berkembang sesuai dengan spirit dan nilai-nilai yang dianut sekolah. Tradisi ini mewarnai kualitas kehidupan sebuah sekolah, termasuk kualitas lingkungan, kualitas interaksi, dan kualitas suasana akademik. Terbentuknya budaya sekolah yang baik dapat membawa perubahan ke arah yang lebih baik, terutama dalam mengubah perilaku peserta didik. Faktor-faktor pembiasaan budaya sekolah melibatkan nilai moral, sikap dan perilaku siswa, komponen yang ada di sekolah, dan aturan/tata tertib sekolah (Kemendikbud, 2017).

Kepemimpinan kepala sekolah dalam membangun karakter siswa. Kepemimpinan dalam membangun karakter siswa tentunya tidak terlepas dari visi dan misi serta tujuan yang dituangkan di dalam program sekolah, dengan adanya penanaman dan pengembangan karakter bulding sekolah mampu membangun kecerdasan emosional siswa secara mandiri dan bekelanjutan sehingga siswa menurut Lickona pendidikan karakter merupakan budaya yang diciptakan disekolah yang bertindak sesuai dengan nilai-nilai dan etika yang telah dituangkan di dalam peraturan sekolah. Kemajuan pengembangan karakter siswa merupakan keberhasilan dan peran penting kepala sekolah dalam mengembangkan karakter kepala sekolah menjadi garda 
2996 Gaya Kepemimpinan Kepala Sekolah Dasar dalam Membentuk Karakter Warga Sekolah - Riki Batubara, Rusdinal, Nurhizrah Gistituati

DOI: https://doi.org/10.31004/edukatif.v3i5.998

terdepan untuk penerapannya dan suksesnya pengembangan nilai-nilai karakter dilihat dari gaya dan cara kepala sekolah mengembangkannya.

Disekolah kepala sekolah menerapkan sholat berjamaah semua guru, dengan tujuan supaya siswa termotivasi juga untuk melaksanakan sholat dan mengajarkan anak dalam disiplin di sekolah, dengan dterapkan sholat berjamaah sebelum siswa pula dan menertibkan siswa pulang secara bersama-sama, sholat berjamaah dilakukan di sekolah untuk mengontrol supaya siswa tidak meninggalkan sholat setelah sampai di rumah, karena membiasakan sholat berjamaah merupakan tanggungjawab guru dalam membangun sifat religi anak. Sejalan dengan penelitian (Gaib., 2019) Kepala sekolah mengambil kebijakan diawal semester jadi perencanaan sudah matang sebelum diberlakukan pendidikan karakter tersebut. Membagun warga sekolah yang berkarakter tidak terlepas dari kebijkan yang dibuat oleh pimpinan. Pimpinan menjadi garda terdepan atas kesuksesan pengembangan karakter siswa masing-masing. Kepala sekolah membuat peraturan atas kesepakatan bersama jadi semua warga sekolah dapat mematuhi bersama-sama jika ada siswa yang melanggar akan diberikan hukuman oleh kepala sekolah dan siswa yang rajin juga akan diberikan reward dengan berbagai bentuk hadiah sehingga siswa yang disiplin dan rajin dapat bersemangat dalam melaksanakan ibadah sholat dan kegiatan relijius lainnya.

Hasil penelitian (Ribuwati, 2019) Strategi yang diterapkan oleh kepala sekolah untuk membangun karakter peserta didik di atas memang sudah cukup efektif, akan tetapi berdasarkan temuan di lapangan pelaksanaan dari ketiga strategi tersebut memang belum bisa $100 \%$ (seratus persen). Mendidik karakter religius dan disiplin itu memang sulit dan harus secara bertahap karena berkaitan dengan banyak orang yang masing-masing memiliki sifat yang berbeda. Dalam pelaksanaannya masih terdapat beberapa guru yang belum mampu melaksanakan tugasnya dengan baik. Masih terdapat beberapa peserta didik yang membutuhkan perhatian khusus. Oleh karena itu, tugas kepala sekolah merangkul semuanya baik guru maupun peserta didik untuk bersama-sama memegang komitmen visi dan misi sekolah.

Pembinaan secara langsung kepala sekolah terhadap bawahan. Pembinaan yang dilakukan oleh kepada sekolah kepada staf, guru dan siswa dilakukan secara personal kepala sekolah menerapkan dalam penggunaan media pembelajaran seperti infokus, karena keterbatasan alat maka pemakaian dilakukan secara bergantian, dan setiap anggota yang sudah menggunakan wajib meletakan kembali ditempatkan dan membuat catatan pengembalian barang pada buku yang telah ditentikan. Menanamkan disiplin dan tenggangrasa merupakan satu aspek karakter bulding yang dibangun di sekolah. Membangun rasa peduli dan kerjasama masih relatif rendah karena tidak semua warga sekolah yang dapat peduli dengan rekan kerja terutama dalam pengguaan media pembelajaran. Sikap jujur terlihat pada saat siswa berbelanja di kantin sekolah, pengelola kantin sekolah memberikan keperncayaan pengelola dalam mengelola kantin jujur, diaman setiap siswa berhak berbelanja dan membayar setalah selesai makan. Disini akan terlihat mana siswa yang jujur dan mana yang tidak jujur. Kejujuran yang ada di dalam diri sulit diperoleh, kebanyakan orang sekali ada kesembatan dimanfaantkan. Kebijakan yang dibuat oleh kepala sekolah guru dan siswa harus menjalankan sesuai dengan kespakatan yang telah dilakukan.

Hasil penelitian (Ekowati, 2020) model kepemimpinan dalam meningkatkan kedisiplinan guru 1) kepala sekolah menerapkan model kepemimpinan demokratik dalam meningkatkan kedisiplinan guru. Hal ini dibuktikan dengan kepala sekolah sangat terbuka, menerima saran dan masukan, serta kritik. Kepala sekolah juga selalu mengajak, mendorong dan memotivasi kepada guru dan karyawan untuk selalu berubah dan mengembangkan diri menjadi lebih baik. Selain itu kepala sekolah mengutamakan musyawarah untuk mencapai mufakat. Sebelum keputusan diambil kepala sekolah memusyawarahkan dengan tim atau stafnya agar diberi masukan dan saran apabila kurang baik, setelah itu disosialisasikan kepada seluruh warga sekolah ( guru dan karyawan), 2) kepala sekolah sangat besar perannya dalam meningkatkan kedisiplinan guru. Kepala sekolah menyusun rencana, program dan melaksanakan program kedisiplinan yang dituangkan dalam tata tertib atau aturan guru. Tata tertib kedisplinan itu berupa: disiplin waktu, disiplin administratif, disiplin 
2997 Gaya Kepemimpinan Kepala Sekolah Dasar dalam Membentuk Karakter Warga Sekolah - Riki Batubara, Rusdinal, Nurhizrah Gistituati

DOI: https://doi.org/10.31004/edukatif.v3i5.998

beribadah, disiplin menegakkan aturan, dan disiplin sikap. Disarankan kepada kepala sekolah agar dapat menerapkan model kepemimpinan secara bervariasi untuk mencapai tujuan yang diinginkan secara maksimal.

Pengembangan karakter dilakukan secara langsung oleh kepala sekolah dengan cara mendampingi guru dalam melaksanakan pembinaan, seperti memantau kegiatan siswa pada saat melaksanakan sholat berjamaah, guru memberikan laporan kepada kepala sekolah jika ada hal-hal yang tidak dapat diselesaikan oleh guru dalam menerapkan disiplin siswa dalam melaksanakan sholat berjamaah, nanti kepala sekolah yang mendatangi dan menanyakan kepada siswa kenapa tidak melaksanakan sholat berjamaah. Namun demikian kepala sekolah memberikan teladan terlebih dahulu dengan cara melaksanakan sholat tepat waktu dan bermajaan di mushola sekolah. Dan semua guru yang tidak mengajar mengikuti sholat tepat waktu sesuai dengan jadwal jam masuk sholah dan siswa yang sudah selesai jadwal pembelajaran diwajibkan mengikuti sholat berjamaah disekolah

Modal yang dimiliki kepala sekolah perlu didorong dengan lima peranan sebagai pemimpin yang efektif. Kelima peranan tersebut adalah sebagai katalisator yang menggairahkan, motivator yang visioner, penghubung yang terkendali, pelaksana yang teguh, dan ahli yang bijaksana. Peranan ini berfungsi untuk menumbuhkan nilai karakter di sekolah, dimana terdapat delapan belas nilai karakter yang terimplementasi dalam setiap aktifitas pembelajaran di sekolah (Trihantoyo, 2015). Karakter pendidikan harus melibatkan berbagai pihak, di keluarga dan rumah tangga, lingkungan sekolah, dan masyarakat. Hal ini merupakan langkah utama yang harus dilakukan ialah menyambung kembali hubungan dan jaringan pendidikan yang nyaris putus diantara ketiga lingkungan pendidikan tersebut. Pembentukan sifat dan karakter pendidikan tidak akan pernah berhasil selama diantara ketiga lingkungan pendidikan tidak ada keharmonisan dan kesinambungan. Melihat kenyataan ini, membentuk karakter siswa yang berkualitas diperlukan pengaruh yang kuat dari keluarga, sekolah, dan mayarakat(Subianto, 2013). pembentukan karakter cinta damai siswa di sekolah tersebut, melalui tipe kepemimpinan kepala sekolah, keteladanan guru dalam pembentukan karakter, dan upaya-upaya pembentukan karakter yang dilakukan pihak sekolah (Syaefudin \& Santoso, 2018). Kepala sekolah agar meningkatkan pendidikan karakter dengan cara lebih sering melakukan kegiatan-kegiatan yang berkaitan pendidikan karakter kepada guru dan peserta didik. Kepada guru hendaknya memahami pendidikan karakter dan mempelajari strategi dan metode yang tepat untuk menerapkan pendidikan karakter yang efektif (Diyanto, Yuliejantiningsih, \& Murniati, 2018) Peran kepala sekolah sebagai pimpinan di sekolah adalah dalam bentuk melakukan pembinaan secara terus- Imenerus dalam hal pemodelan (modeling), pengajaran (teaching), dan penguatan karakter (reinforcing) yang baik terhadap semua warga sekolah (guru, siswa, dan karyawan) (Widodo, 2018). Kepala sekolah turut mengevaluasi jalanannya sistem poin dan sanksi disiplin di sekolah. (2) Gambaran penanaman pendidikan karakter disiplin : (a) masih banyak siswa yang membolos, merokok di sekolah, serta telat(Cahyani \& Jurusan, 2018).

Gaya kepemimpinan kepala sekolah yang berkarismatik dapat meningkatkan keinovatifan guru dalam tugas dan pekerjaan, karena kepala sekolah sebagai pemimpin mengetahui dengan pasti dan yakin apa yang menjadi tujuan dari proses pendidikan, kepala sekolah dapat mempengaruhi seluruh warga sekolah untuk mencapai tujuan tersebut. Guru yang berinovatif akan mempengaruhi dalam kepemimpinan karismatik kepala sekolah, salah satu gaya kepemimpinan yang fenomena luntuk membentuk mutu pendidikan didimasa yang akan dating dengan membawa harapan menciptakan karya inovasi yang lebih baik (Sutianah, Sunaryo, \& Yusuf, 2018).

\section{KESIMPULAN}

Gaya kepala sekolah dalam membangun nilai-nilai karakter di SDN 12 Melintang Pasaman Barat dengan cara membuat perencanaan terlebih dahulu, setelah perencanaan dibuat kepala sekolah mendiskusikan dengan guru karakter apa saya yang akan dikembangan, dari hasil kesepakatan karakter yang dikembangkan 
2998 Gaya Kepemimpinan Kepala Sekolah Dasar dalam Membentuk Karakter Warga Sekolah - Riki Batubara, Rusdinal, Nurhizrah Gistituati

DOI: https://doi.org/10.31004/edukatif.v3i5.998

ada karakter jujur, tanggungjawab, religi dan kerjasama, saat ini pengembangan kecerdasan emosional perlu dibangun, saat ini karater siswa sudah banyak dipengaruhi oleh dunia luar terutama tetang etika dan sopan santun, kepala bersama guru menerapkan sholat berjamaan dan membaca kultum setiap hari jumlah, sholat berjamaah dilakukan sebelum semua siswa pulang dalam hal ini kepala sekolah menjaga agar sholat siswa tidak ketinggalan dan sepulah sekolah siswa bisa langsung makan dan melaksanakan rutinitas lainnya. Saran yang dapat diberikan diharapkan kepala sekolah tetap menjadi teladan bagi guru terutama dalam menerapkan kedisiplinan dari semua aspek.

\section{DAFTAR PUSTAKA}

Ananda, R. (2017). Penerapan Pendekatan Problem Solving Untuk Meningkatkan Hasil Belajar Pada Mata Pelajaran IPS Siswa Kelas IV SD. Jurnal Sekolah, 1(2), 66-75.

Ananda, R., Fadhilaturrahmi, F., \& Hanafi, I. (2021). Dampak Pandemi Covid-19 Terhadap Pembelajaran Tematik Di Sekolah Dasar. Jurnal Basicedu, 5(3), 1689-1694.

Arikunto, S. (2010). Arikunto, Suharsismi. 2010. Prosedur Penelitian Suatu Pendekatan Praktek. Jakarta: PT. Rineka Cipta.

Cahyani, L. I., \& Jurusan. (2018). Pendidikan Karakter, Kedisiplinan, Kepala Sekolah. 2(1), 1-7.

Claudy Yanar Yasuka. (2018). Kebijakan Kepala Sekolah Dalam Mengembangkan Pembangunan Karakter Pengajaran Peserta Didik SDN Mojosongo V Surakarta. In Biomass Chem Eng (Vol. 3).

Diyanto, D., Yuliejantiningsih, Y., \& Murniati, N. A. N. (2018). Peran Kepala Sekolah Dalam Implementasi Pendidikan Karakter Di Smp Pgri Purwareja Klampok Kabupaten Banjarnegara. Jurnal Manajemen Pendidikan (JMP), 7(3), 345-362. Https://Doi.Org/10.26877/Jmp.V7i3.3149

Ekowati, E. R. (2020). Model Kepemimpinan Kepala Sekolah Dalam Meningkatkan Kedisiplinan Guru Di SMK Muhammadiyah Se- Kabupaten Magelang Oleh : Universitas Muhammadiyah Magelang I.

Fadhilaturrahmi, F., Ananda, R., \& Yolanda, S. (2021). Persepsi Guru Sekolah Dasar Terhadap Pembelajaran Jarak Jauh Di Masa Pandemi Covid 19. Jurnal Basicedu, 5(3), 1683-1688.

Gaib, N., Najamuddin Pettasolong, \& Satria Koni. (2019). Peran Kepemimpinan Kepala Madrasah Dalam Meningkatkan Disiplin Sholat Berjamaah Peserta Didik. Tadbir: Jurnal Manajemen Pendidikan Islam, 7(2), 126-130. Https://Doi.Org/10.30603/Tjmpi.V7i2.1114

Guna, D., \& Tugas, M. (2016). Program Pasca Sarjana Manajemen Pendidikan Islam Tahun 2016. 1-22.

Kamaruddin, Murniati, \& Niswanto. (2016). Pendidikan Karakter Pada Sekolah Menengah Atas Negeri 1 Julok. Jurnal Administrasi Pendidikan Pascasarjana Universitas Syiah Kuala 11, 4(1), 82-92.

Kemendikbud. (2017). Penguatan Pendidikan Karakter Modul Pelatihan Bagi Kepala Sekolah.

Marianti, M., Razak Umar, \& Ruwiah A. Buhungo. (2019). Gaya Kepemimpinan Kepala Madrasah Dalam Meningkatkan Kompetensi Pedagogik Guru Di Madrasah Ibtidaiyah Kota Gorontalo. Tadbir: Jurnal Manajemen Pendidikan Islam, 7(2), 148-153. Https://Doi.Org/10.30603/Tjmpi.V7i2.1127

Ribuwati. (2019). Kepemimpinan Kepala Sekolah Dalam Membangun Karakter Peserta Didik Di Sekolah Menengah Atas Negeri 1 Belitang Kabupaten Oku Timur. Universitas PGRI Palembang.

Satim, A. (2013). Pada Pendidikan Dasar. Al Badiyah, 5(2), 157-179.

Subianto, J. (2013). Peran Keluarga, Sekolah, Dan Masyarakat Dalam Pembentukan Karakter Berkualitas. Edukasia: Jurnal Penelitian Pendidikan Islam, 8(2), 331-354. Https://Doi.Org/10.21043/Edukasia.V8i2.757

Sutianah, E., Sunaryo, W., \& Yusuf, A. E. (2018). Hubungan Antara Gaya Kepemimpinan Karismatik Kepala Sekolah Dan Kepribadian Dengan Keinovatifan Guru. Jurnal Manajemen Pendidikan, 6(2), 654-662. 
2999 Gaya Kepemimpinan Kepala Sekolah Dasar dalam Membentuk Karakter Warga Sekolah - Riki Batubara, Rusdinal, Nurhizrah Gistituati

DOI: https://doi.org/10.31004/edukatif.v3i5.998

Https://Doi.Org/10.33751/Jmp.V6i2.792

Syaefudin, S., \& Santoso, S. (2018). Tipologi Kepemimpinan Kepala Sekolah Dalam Pembentukan Karakter Cinta Damai Siswa SMP Piri 1 Yogyakarta. Manageria: Jurnal Manajemen Pendidikan Islam, 3(1), 4767. Https://Doi.Org/10.14421/Manageria.2018.31-03

Trihantoyo, S. (2015). Peranan Kepemimpinan Kepala Sekolah Dalam Menumbuhkan Nilai Karakter. Jurnal Manajemen Pendidikan, 10 Nomor 3, 25-35.

Widodo, H. (2018). Strategi Kepala Sekolah Dalam Mengembangkan Pendidikan Karakter Di Sekolah Dasar Muhammadiyah Sleman. Metodik Didaktik, 13(2), 69-80. Https://Doi.Org/10.17509/Md.V13i2.8162 